\title{
Sandra Williams
}

University of Brighton, UK

sjw7@brighton.ac.uk

\section{On the Cusp of the Canon: English Children's Literature in the First Half of the $19^{\text {th }}$ Century}

Izvorni znanstveni rad / original research paper

Primljeno / received 18. 7. 2019. Prihvaćeno / accepted 29. 6. 2020.

DOI: $10.21066 /$ carcl.libri.2020.1.1

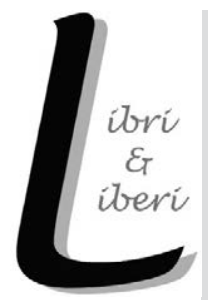

This period, the first half of the $19^{\text {th }}$ century, stands on the cusp of the first Golden Age of English children's literature. While publications from the mid-1800s onwards, such as Alice's Adventures in Wonderland, The Secret Garden and The Wind in the Willows, have become part of the cultural landscape, those from the first half of the $19^{\text {th }}$ century are largely unfamiliar and forgotten. If read at all, they are studied by academics rather than read by children. Publications at that time reveal the tensions between the perceived need for improving, moralising books and those that might give pleasure to the reader. It will be argued in this article that amongst the more didactic works, there are indicators of what was to follow. Attention is drawn to chapbooks for children and to a number of titles which have enjoyed a degree of longevity.

Keywords: canon, chapbooks, moralising, construction of childhood

Whilst there is no established canon in English children's literature, there is a [popularly] recognised first Golden Age which begins in the second half of the $19^{\text {th }}$ century and ends at the outbreak of World War I in 1914. The books published in this period are still in circulation and continue to appear in a variety of media. During this period, the genre of the school story developed after the publication of Tom Brown's School Days (Hughes 1857); animals become a central focus in many stories such as Black Beauty (Sewell 1877), The Jungle Book (Kipling 1894) and The Wind in the Willows (Grahame 1908); and nonsense was legitimised in Alice's Adventures in Wonderland (Carroll 1864). High adventure appears in Treasure Island (Stevenson 1883), domestic realism in The Railway Children (Nesbit 1906) and The Secret Garden (Hodgson Burnett 1911). In addition, plays specifically for children first appear with Peter Pan (Barrie 1904). 
It is recognised that the term 'canon' is far from straightforward, particularly in the case of literature for children. Thus, Marina Balina's (2019) identification of three strands when discussing canon is helpful:

1 Academic: read only by those lecturing/conducting research and their students.

2. Sentimental/emotional: memory of childhood reading; preservation of a notion of childhood.

3. Popular: commercial, mobile and often unstable. Hence what was popular in one period becomes unknown in another.

As such, these Golden Age texts fall into all three categories: they are read and analysed by academics; they are recycled for generations of young readers which means there is an emotional connection to childhood; and, finally, mobility is one reason for their continuing popularity, as these stories appear in a variety of media.

Of particular significance in this period is the establishment of a different kind of relationship between author and younger reader. Books are no longer didactic and moralising, focusing on improving the mind with characters acting as exemplars; rather, the focus is on entertaining the reader through emotional evocation.

In contrast, books published in the first half of the $19^{\text {th }}$ century are largely known only to academics and, while popular at the time, most have vanished into obscurity. Hence, there is little emotional attachment. So this raises the question as to what led to this first Golden Age of English children's literature. In this article, I present those publications which might have influenced what was to follow. The significance of the construction of childhood, a dominant ideology, and the material circumstances surrounding publication underpin the discussion.

\section{Background}

Before we focus on the early 1800s, it will be useful to set the context by briefly reviewing how books for children had developed in England in the previous 200 years. There are a number of useful publications which trace this history and my main sources have been Townsend (1974) and Hunt (1994) who offer a historical trajectory. However, it should be kept in mind that the following is just a brief summary without the nuances that a more detailed analysis would reveal. Those who are interested might wish to read the work of Horne (2016), Grenby (2011), Demers (2008) and the extensive publications of Mitzi Myers.

Books specifically for children were first published by the Puritans in the $17^{\text {th }}$ century after the English Revolution in 1649 when the monarchy was overturned and a Republican Commonwealth declared in which Parliament was dominant. Those in power were Puritans who strongly believed in Original Sin into which everyone is born and must be saved if they are to go to heaven.

With high infant mortality, it was imperative that children led a good Christian life, so there was no time for frivolity. Consequently, children's books were devoted to stories of young children leading exemplary lives. The most well-known example is $A$ 
Token for Children by James Janeway first published in 1692 and consisting of accounts of young children dying well. The Preface includes a number of directions to the young reader, where point 3 informs them what happens to children who tell lies and never pray (Janeway 1799 edition):

[...] they which lie must go to their father the devil, into everlasting burning; they which never pray, God will pour out his wrath upon them; and when they beg and pray in hell fire, God will not forgive them, but there they must lie forever.

The Preface ends with a series of instructions for children which, for a reader in the 2020s, is likely to seem more like coercive control than helpful advice.

Here is an account of a dying child as an exemplar (Janeway 1799: 16, 17):

Upon the Lords Day she scarce spoke anything, but much desired that Bills of Thanksgiving be sent to those who had formerly been praying for her [...] and seemed to be much swallowed up with the thoughts of Gods free love to her soul. She oft commended her spirit into the Lords hands, and the last words which she was heard to speak were these, Lord Help, Lord Jesus help, Dear Jesus, Blessed Jesus - And Thus upon the Lords Day, between Nine and Ten of the Clock in the Forenoon, she slept sweetly in Jesus, and began an everlasting Sabbath. February $19^{\text {th }}, 1670$.

The precise date of the death of the child offers a sense of veracity, and in each account of a death the reader is given to understand that what they are reading actually took place. The use of the first person: "In whose bosom he sweetly slept, dying, as I remember, when he was about five or six years old" (Janeway 1799: 25) offers authenticity. Of another account there is reference to a witness "[...] this narrative I had from a judicious holy man, unrelated to him, who was an eye and ear-witness to all these things" (75).

Perhaps such stories offered solace to bereaved parents. While appearing inappropriate for children now, it should be borne in mind that literacy was considered important for Puritans as their faith focused on reading the Bible. Hence, emphasis on the written word encouraged wider literacy, which in turn supported the publishing industry. Besides, there was a growing middle class who had surplus money for items such as books, and so printers and publishers began to see a market in children's material. Another well-known author was Isaac Watts whose Divine Songs for Youth published in 1715 was also popular. Perhaps best known is this poem in which a strong reference to the Protestant work ethic appears in the final verse (Watts 1837: 105-106):

How does the little busy bee

Improve each shining hour,

And gather honey all the day

From every opening flower

$[\ldots]$

In work of labour or of skill

I would be busy too,

For Satan finds some mischief still

For idle hands to do. 
The poem remained in circulation, as evidenced by the 1837 edition, published in Paris, cited above, reprinted in chapbooks and was parodied by Lewis Carroll (both discussed below).

While the Puritans lost political power when the Monarchy was restored in 1660, their ideas survived for some time and many migrated to America. Further developments in publishing for children were brought about by significant changes in the construction of childhood. While it is recognised that a number of differing critical approaches to such changes could be discussed at this point, in the interests of brevity a broad general view is taken as follows. Under the influence of the Enlightenment and subsequent Romantic Movement, the child was now seen as born in innocence, and such innocence was to be celebrated and nurtured. This led to more entertaining material, the most wellknown being John Newbery's Little Pretty Pocket Book (1744) which had giveaways: a ball for a boy and a pincushion for a girl. While clearly gendered, this might have been the same item and hopefully a girl could choose whether to stick pins in it or kick it about. However, although there was more room for entertaining books, there remained a strong didactic element where it was considered important for books for children to be both moralising and instructional. There was little time for fantasy and fairy stories, a mainstay of children's books today. The Religious Tract Society was founded in 1799 which mass-produced affordable books that were distributed in such places as Sunday schools run by church groups. The aim was to ensure that all contained "some account of the way of a sinner's salvation" (Bratton 1981: 33).

The key authors of this period were women: Barbauld, Edgeworth, More, Trimmer, and Sherwood who spans the centuries. The work of these authors will be referred to below.

\section{Situation at the beginning of the $19^{\text {th }}$ century}

This brings us to the first half of the $19^{\text {th }}$ century. In terms of commercial work, there was demand for books for children promoted by printers/publishers. Fewer children died as infants, literacy was increasing, there was a little more money to spend, and books for children were sold in bookshops or through catalogues for an increasing middle class (Grenby 2011). Most were in the genre of realism and remain essentially moralising works. Notable too are titles from previous centuries referred to above which were still in circulation.

But we need to remember children from the poorer classes were working and the Education Act legislating for Elementary Education did not come in until 1870. The average wage for an agricultural worker in the early 1800 s was $£ 40$ per annum, $£ 60$ for a skilled worker and at the top lawyers and barristers at $£ 447$. Hence a book which might cost 3 shillings ( 12 pence $=1$ shilling; 20 shillings $=£ 1$ ) would be prohibitively expensive for the working classes.

This brings us to publications which are less well known but are significant in terms of their influence on what was to follow in the second half of the $19^{\text {th }}$ century. 


\section{Chapbooks and the oral tradition}

Running alongside written texts is the oral tradition which would have been heard by both adults and children. Folk tales, myths and legends were passed on orally both through telling and singing. Importantly, this tradition influenced the chapbook culture. Chapbooks were small and cheap, costing pennies rather than shillings and, as sold by travelling salesmen, were widely accessible. Some of these texts were appropriate for children, as evidenced by printers' catalogues, but by the early $19^{\text {th }}$ century chapbooks specifically for children were published once a market was created for them. Such publications fell beneath the radar and a wider variety of genres appeared compared to the "legitimate" more costly books to be found in bookshops.

The British Library holds the Henry Mayor Lyon collection of children's chapbooks from the first half of the $19^{\text {th }}$ century. These have been the basis for my research to discover what was published for children in this format. Of a collection of over 200 titles, 80 are catalogued electronically while an early file-card system is also available which contains all publications. Often the author is not acknowledged nor is the engraver of the woodcuts. Rather, it is the publisher and/or printer who is foregrounded. Grenby (2008) notes that this is the case with the majority of books for children before the $20^{\text {th }}$ century. When the books are handled for the first time, the small size and thin paper are striking features which are less obvious with digital viewing. Engaging woodcuts serve to relieve the often small print. What is notable is they cover a wide range of reading material. I have categorised the 80 electronic items as follows:

\section{Fiction}

\section{Realism}

Exemplary children: such as the deaths of children, e.g. The Little Saint: or, The Life and Death of Mary Grant... sold by among others J. Nesbitt and J. Kershaw, London 1824.

Moralising tales: some with known authors such as Mary Martha Sherwood. These are short stories rather than longer novels.

\section{Fantasy}

Animal Stories: e.g. The History of Fowler and Keeper, Two Dogs (pub. Arliss, J., 1815).

Oral Tradition: folk tales including those translated from other language such as A Thousand and One Nights plus the home grown The Seven Champions of Christendom.

Legends including Robin Hood.

\section{Fables}

Versions of adult fiction such as Robinson Crusoe.

Humour: anecdotes, riddles, nonsense, e.g. The Anecdote Book: A Selection of Amusing Anecdotes for Children, printer W. Davison 1840.

Drama: scripts for toy theatres (on the card-index file only). 


\section{Non-Fiction: (fewer in this category)}

Biology

History

Geography

Literacy: $\mathrm{ABCs}$, short reading passages accompanied by woodcuts (might be seen as an early form of picturebook).

\section{Religious}

Prayers: e.g. Short Prayers for Young Men and Lads in Farm Houses printed at Boynton 1859.

Bible stories

Reprints such as: Divine Songs by Isaac Watts. Further evidence that such texts remained in circulation is the parody in Alice's Adventures in Wonderland in which the busy bee referred to above is changed into something more alarming (Carroll 1865/1982: 19):

How doth the little crocodile,

Improve his shining tail,

And pour the waters of the Nile,

On every golden scale!

How cheerfully he seems to grin,

How neatly spreads his claws,

And welcomes little fishes in,

With gently smiling jaws!

Some clearly have a child audience in mind, while others have language that is challenging. An example is a version of the legend of Robin Hood which has very small print, and much description, hence making it more suitable for a literate adult reader. Others have larger print with more woodcuts and are thus more likely to appeal to the apprentice reader. Short stories concerning identifiable young characters written in a friendly voice indicate a sense of the young reader's needs.

The significant point about these books is they were widely available, affordable, commercially viable and offered more than moralising works. In addition, in some there are signs of a changing relationship with the reader.

Two short stories by Maria Martha Sherwood offer an example of this developing relationship. In The Shawl (1840), which cost 1 penny, the reader is addressed directly regarding a woodcut: "Here you may see her kneeling at her drawers, about to take out her walking things". This is interesting for two reasons. Firstly, clearly the author had some control over the publication as she knew which woodcuts would be included and so was able to guide her reader. Secondly, it demonstrates an attempt at forming a kindly relationship which is echoed as the tale comes to a close with a more direct form of address: "Now my little readers". Having thus entertained and drawn her readers in, inevitably there follows a moralising ending. In The Hedge of Thorns (1827), there is 
direct address this time through a first person narrative which opens: "My name is John Carrol" and continues with John's early life and subsequent fall from grace through drinking too much ale. The first-person narrative ends suddenly, after which Sherwood uses an interesting framing device to complete the story as follows (ibid):

The above account of John Carrol, which seems to have been broken off abruptly, probably by the approach of his last illness, was found in the leaves of his Bible sometime after his death.

While still overtly moralising, the above are examples of a developing relationship with the reader which is seen later in the work of E. Nesbit. Such direct address is not new and goes back to Janeway but there is a shift from a more distanced authorial stance to a closeness to the reader. There are a number of stories which appear from the titles to be biography offering verisimilitude but are in fact fiction.

In terms of fantasy, tales from the oral tradition were kept alive and the books set a style and an imagining which appear in subsequent original stories. An example which has echoes of the folk tale is Fortune's Favourite - The History of the Wonderful Purse and Wishing Hat of Fortunatus (1810). Subsequently, it appears in the more prestigious Andrew Lang's Grey Fairy Story Book published in 1900. In the $20^{\text {th }}$ century, the Wishing Hat appears to have had some influence on the Sorting Hat in J.K. Rowling's Harry Potter series.

Animals feature in many stories, both in a naturalistic setting and as fantastical talking beasts which may have influenced subsequent publications. Black Beauty by Anna Sewell follows the life of a horse, and there are numerous talking animals in Alice's Adventures in Wonderland, as well as those inhabiting Rudyard Kipling's Jungle Books.

There are not many texts in the non-fiction category. However, the way factual information was conveyed by one particular author is of interest. With titles such as The Pearl Bracelet (1835) and The Coral Necklace (1835), Lucy Sarah Atkins Wilson frames information around the activities of a fictional family. For example, in The Pearl Bracelet the children, Caroline and Arthur, find a broken pearl bracelet on a walk and take it home. Mother then explains how pearls are formed, after which there follows some geography in locating the places where pearls are found, with Caroline then looking them up in her Atlas. Mother also offers detail about diving for pearls, with some sympathy for those who have to dive for pearls in order to make a living. Information on the poor living conditions and poverty of the Irish peasants is offered by Father after Arthur has copied a sketch of an Irish cabin. This is followed by comparing peasant life in Scotland where close attention is given to Bible reading. The latter is more sympathetically viewed than the former, demonstrating the negative attitudes towards Catholic Ireland commonly held by the English establishment at that time. Similarly, in The Coral Necklace, Mother seizes the opportunity to explain the origins of coral to her daughter who cherishes her coral necklace and this leads to more explanation of the manufacture of silk, linen and wool. This is a genre termed the 'conversational primer' developed by Barbauld in the previous century in publications for the middle classes (Lim 2002). What is significant is that now they appear in a form which is affordable for a wider range of readers. 
On a less serious note there is nonsense, usually un-authored; a good example is a humorous tale about a woman who buys a pig at a fair which ends as follows:

The cat flew at the rat,

The rat ran to the rope,

The rope ran to the man,

The man ran to the pig,

And the pig went home,

Like a good pig.

Chapbooks are important because they maintain the fantasy of the oral tradition which became the bedrock of later more "legitimate" publications for children, offered readers a range of reading material for little cost, and gave publishers the opportunity to develop their market.

\section{Survivors}

In terms of books which were less ephemeral and more for a middle class readership where parents could afford to pay shillings rather than pennies, I will now present nine texts which may have influenced what was to come and, while less well known compared to later publications in the first Golden Age, remain in the cultural landscape. It is worth keeping in mind that these books may have been read as children by authors of the first Golden Age.

The Star (1805), better known from the opening line: 'Twinkle, twinkle little star', appears in a book of poems for the nursery written by sisters Ann and Jane Taylor. It cost 3 shillings, so clearly was aimed at the relatively affluent. It was put to music, based on a French tune on which Mozart composed variations, and it is still sung by children in primary schools today. It is also used to teach those learning English as a foreign language. Lewis Carroll knew it, as it was parodied as 'Twinkle, Twinkle Little Bat' in Alice's Adventures in Wonderland.

In Sarah Martin's The Comic Adventures of Old Mother Hubbard and Her Dog (1805), a dog variously smokes a pipe, plays the flute, rides a goat, and reads the news. There is no narrative, with each page offering a different antic:

She went to the Garden

To get him a Pippin,

When She came back

The dog was Skipping.

This is a fine example of nonsense verse stemming from the oral tradition, carried on in chapbooks and now published with a named author. According to Muir (1969), there were spin-offs in the form of handkerchiefs, jigsaw puzzles and card games.

William Roscoe's story in verse, The Butterfly's Ball (1807), tells a tale of insects arriving for the ball:

Come take up your Hats, and away let us haste

To the Butterfly's Ball, and the Grasshopper's Feast. 
The Trumpeter, Gad-fly, has summon'd the Crew,

And the Revels are now only waiting for you.

There are fanciful insects, anthropomorphism and absurdity with no moralising. It was very popular and may well have influenced both Carroll and Tenniel, author and illustrator of Alice's Adventures in Wonderland, in particular the hookah-smoking caterpillar perched on a mushroom, for in the poem a large mushroom is used as a dining table. The poem reappears in 1973 in a version by Alan Aldridge and William Plomer which won the Whitbread Award. This version was later republished by Templar in 2009 with an illustration on the front page which includes Carroll's Humpty Dumpty. Subsequently, it became an animation and then a rock opera by Roger Glover. So, although less well known, it does continue to circulate.

Charles and Mary Lamb were unhappy with the preponderance of moralising works, and in a letter to Coleridge in 1802 Charles Lamb described what was on offer at Newberry's bookshop (Hunt 1994: 47):

Mrs Barbauld's stuff has banished all the old classics of the nursery, and the shopman at Newberry's hardly deigned to reached [sic] them off an old exploded corner of a shelf, when Mary asked for them. Mrs Barbauld's and Mrs Trimmer's nonsense lay in piles about $[\ldots]$

This experience led to the writing of Lamb's Tales from Shakespeare (1807) carefully adapted for the young reader and remains in circulation, continuing to offer an introduction to the plays for children.

The Holiday House (1839) by Catherine Sinclair focuses on a pair of exceptionally naughty children and is full of humour and fun. The preface indicates Sinclair's attitude towards childhood (xiv):

In this age of wonderful mechanical inventions, the very mind of youth seems in danger of becoming a machine; and while every effort is used to stuff the memory, like a cricket-ball, with well-known facts and ready-made opinions, no room is left for the vigour of natural feeling, the glow of natural genius, and the ardour of natural enthusiasm.

Although it was reprinted in the 1970s it is less known today but signified an important change in how childhood could be constructed. For far from demonstrating exemplary behaviour, the two children set fire to their nursery, ruin their clothes, invite friends to tea without telling cook and generally create mayhem.

Considering how popular the legend of Robin Hood is, and even though it was first published by Wynkyn de Worde in the $15^{\text {th }}$ century, it did not feature strongly in this period. But it does appear earlier in chapbook form and stems from the oral tradition. It was as late as 1841 that Robin Hood and his Merry Foresters by Stephen Percy (aka Cundell) appears in a version for children. Politically sensitive, concerning the hero Robin Hood taking from the rich and giving to the poor, this legend lurked under the radar in the chapbook rather than in more legitimate published books. Once legitimised, it has since appeared in numerous iterations including a TV series in 1955, 
a more recent one in 2006 and many films including Mel Brooks' satirical Robin Hood: Men in Tights.

The Pied Piper of Hamelin is best known in the UK through the poem by Robert Browning (1842). As with the case of Robin Hood, this legend from the oral tradition has enjoyed many iterations. Originally a German tale from the $14^{\text {th }}$ century, it was translated into English by Verstegan in 1605 which became the basis for the poem. It has appeared in many forms: Goethe wrote a version in 1803; the Grimm brothers in Deutschen Sagen in 1816; a Disney cartoon in 1933; a 1957 NBC film; a British film in 1972; in 1986 a Czech animation by Jiri Barta based on a 1915 retelling by Viktor Dyk called "Krysař". (Dyk, by the way, unfortunately drowned in Croatia around the island of Lopud). There is an opera, a Charlie Browne version, a Terry Pratchett parody called Amazing Maurice and his Educated Rodents (2001), and he makes a small appearance in the film Shrek Forever After. In addition, there are Japanese and South Korean versions.

Edward Lear's A Book of Nonsense (1846) remains in circulation with many iterations. Of interest is a dramatic version produced by the Czech dissident theatre group, Husa na Provázku, in Brno. In Přiběhy Dlouhého Nosu [Long Nosed Tales] the actors used Lear's nonsense verse to critique the then totalitarian regime. It remained in the repertoire after the fall of the Berlin Wall in November 1989 and the author of this article advised on an international version partly in English which subsequently went on tour.

Considered to be the first historical novel for children, Children of the New Forest by Captain Marryat (1847) is set at the time of the English Civil War in which the Puritans, discussed above, were dominant. While not necessarily read now, it is known through no less than four BBC TV serialisations in 1955, 1964, 1977 and 1998. The historical novel remains a popular genre in England both with adults and children, exemplified perhaps by Hilary Mantel winning the prestigious Booker Prize twice with her historical novels set around the time of Henry VIII: Wolf Hall (2009) and Bring Up the Bodies (2012).

It should be kept in mind, however, that the most popular book which saw a number of editions is Mary Martha Sherwood's The History of the Fairchild Family (1818). The most infamous episodes are where the children are taken to see a gibbet and later the corpse of a dead gardener (Townsend 1974: 46):

When they came to the door they perceived a kind of disagreeable smell, such as they had never smelt before; this was the smell of the corpse, which having been dead now nearly two days had begun to corrupt [...] the whole appearance of the body was more ghastly and horrible than the children expected [...]

Unsurprisingly, this moralising evangelical work has not stood the test of time.

With reference to the three categories of the canon, all of the above are of interest to academics and some will have a sentimental attachment, particularly The Star, as children still sing it today. In terms of popularity, those that remain popular are mobile, appearing in a range of different media. 


\section{Legacy}

What is the legacy of such publications for children in this period? And why have some of these books remained in circulation? Clearly, they laid the ground for what was to follow.

Stories from the oral tradition were kept in circulation through chapbooks. Such tales are tried and tested, with a familiar structure that can be changed according to the audience. This also includes a link between Lear and earlier nonsense rhymes and riddles such as "Old Mother Hubbard". Significantly, nonsense and riddles pervade both Alice books.

What is also important is the development in realism. While many evangelical works have not stood the test of time, the familiar setting, more rounded characters, and realistic conversations prepared the ground. Through both chapbooks and more "legitimate" publications a closer relationship between author and reader develops. Such a sense of audience may have been supported by reactions from children hearing early versions, as many titles discussed above were first told to actual, real children. In this way, the author is offered immediate feedback and can hone their material. This applies to The Butterfly's Ball, first told to Roscoe's 10 children; The Holiday House was initially told to a group of children; and Browning's poem Pied Piper of Hamelin was recited to a friend's son who was ill in bed. Lear tried out his limericks on the Earl of Derby's grandchildren. And we can think of subsequent publications told originally to children: Alice's Adventures in Wonderland, The Wind in the Willows and Winnie the Pooh.

Another reason they remained in circulation is their adaptability, from a musical version of The Star, to cartoon versions of the Pied Piper of Hamelin, and numerous TV and film versions of Robin Hood. In the UK, pantomime kept many tales from the oral tradition alive and continues to do so. However, once popular tales such as The Seven Champions of Christendom concerning the heroics of saints were probably not appropriate for the rough and tumble of pantomime and, although popular once, the mentioned tale is now only known by academics.

\section{What is missing?}

During the course of this research I became aware that one category in terms of the children's chapbook collection is missing, as I have not seen anything concerning Greek and Roman mythology. Such tales had been in the public domain since the Renaissance: in adult poetry, drama, art and music, yet do not appear in children's chapbooks. Indeed, there are only a few titles concerning classical mythology in the more expensive publications in the period under discussion. William Godwin's The Pantheon, or Ancient History of the Gods of Greece and Rome (1805) intended for school use was adopted by the Charterhouse School and other public (elite fee-paying) schools. At 5 shillings, this was an expensive purchase. As indeed was Charles Lamb's The Adventures of Ulysses (1807) which cost 4 shillings. Charles Kingsley's The Heroes (1855) featuring Perseus, The Argonauts and Theseus might just be squeezed in although just beyond 1850. Boys 
from wealthy families learnt Greek and Latin in their public schools where knowledge of such languages was required for entry to university. Girls from well-off families may have been tutored in the Classics at home. Notwithstanding, the absence of such tales in the chapbooks meant that the social capital synonymous with studying the Classics was denied to those with only pennies to buy their reading material.

\section{Conclusion}

To sum up, the lesser known first half of the $19^{\text {th }}$ century was a fertile place for the development of children's literature in England due to a combination of factors. It can be argued that the chapbooks lurking under the radar maintained aspects of the oral tradition ready to be tapped into once the moralising tale lost its stranglehold. Writers of moralising tales began to develop a more child-friendly style in order to form a relationship with their younger readers. This is echoed by Demers (2008) who asserts that chapbooks "[...] have enduring importance in the history of children's literature" (105) as they created a new market for books, provided inexpensive reading material thus supporting literacy and "[...] the popularity of chapbooks drew to the attention of serious writers the fact that there was a specific audience, young and keen, waiting to be introduced to new works of the imagination" (ibid.).

After the first 50 years of the $19^{\text {th }}$ century, there are additional factors which might appear mundane but are important in the development of children's literature: in the 1860s, paper was cheaper, efficient steam-driven rotary presses were in use, more reliable distribution was established, there were relatively higher levels of literacy and growing numbers of wage earning boys, and there was cheap labour offered by writers and illustrators.

All in all, with a developed publishing industry, writers learning their craft, variety in terms of genre, and a more sympathetic construction of the child, the stage was set for the first Golden Age of children's literature in England.

\section{References}

\section{Primary Sources}

A collection of books for children in chap-book form, for the most part anonymous. Formerly part of the collection of Henry Mayor Lyon 1790?-1860? [sic] held at the British Library, London: The British Library. <https://www.bl.uk>.

Carroll, Lewis. 1865/1982. Alice's Adventures in Wonderland. World's Classics. Oxford: OUP. Janeway, James. 1799. A Token for Children: Being an exact account of the conversion, holy and exemplary lives, and joyful deaths of several young children. [Reprint, first published 1971-1972]. Leeds: J. Binns.

Sinclair, Catherine. 1839/1977. The Holiday House. London: Hamish Hamilton.

Watts, Isaac. 1837. Against Idleness and Mischief. [Reprint]. In Juvenile Poetry: consisting of original poems, by Isaac Watts; Charlotte Smith; John Gay, etc. Paris: Truchy, Beaulé and Jubin. 


\section{Secondary Sources}

Balina, Marina. 2019. A Runaway Canon: Children's Classics, Cultural Politics, and (Re)Writing National Identity in the Former Soviet Bloc. Keynote given at Beyond the Canon (of Children's Literature), Zadar, May 2019.

Bratton, Jacqueline Susan. 1981. The Impact of Victorian Children's Fiction. London: Croom Helm.

Briggs, Julia, Dennis Butts \& Matthew O. Grenby, eds. 2008. Popular Children's Literature in Britain. Aldershot: Ashgate.

Demers, Patricia, ed. 2008. From Instruction to Delight: An Anthology of Children's Literature to 1850. Don Mills, Ont: Oxford University Press Canada.

Grenby, Matthew O. 2011. The Child Reader 1700-1840. Cambridge: CUP.

Horne, Jackie C. 2016. History and the Construction of the Child in Early British Children's Literature. Abingdon: Routledge.

Hunt, Peter. 1994. An Introduction to Children's Literature. Oxford: OUP.

Hunt, Peter, ed. 2001. Children's Literature: An Anthology 1801-1902. Oxford: Blackwell.

Lim, Jessica Wen Hui. 2002. Barbauld's Lessons: The Conversational Primer in Late $18^{\text {th }}$ Century British Children's Literature. $18^{\text {th }}$ Century Studies 42 (1): 101-120.

Muir, Percy. 1969. English Children's Books. London: Batsford.

Townsend, John Rowe. 1974. Written for Children. Harmondsworth: Penguin Books.

\section{Sandra Williams}

Sveučilište u Brightonu, UK

\section{Na rubu kanona: engleska dječja književnost u prvoj polovici 19. stoljeća}

Razdoblje prve polovice devetnaestoga stoljeća stoji na samom rubu prvoga „zlatnoga doba" engleske dječje književnosti. Dok su djela objavljena od sredine toga stoljeća nadalje, poput romana Aličine pustolovine u Čudozemskoj, Tajni vrt i Vjetar u vrbama, postala dio kulturnoga krajobraza, ona iz prve polovice devetnaestoga stoljeća uglavnom su nepoznata i zaboravljena. Ako ih se i čita, čitaju ih znanstvenici i stručnjaci radi akademskoga istraživanja, a ne djeca. Naslovi objavljeni u to vrijeme otkrivaju napetosti između uočene potrebe za primjernim, moralizirajućim knjigama i onima koje bi čitatelju mogle ponuditi razonodu. U radu se pokazuje da među poglavito didaktičnim djelima postoje naznake onoga što će uslijediti. Posvećuje se pozornost jeftinim sveščićima za puk (chapbooks) koje su bile namijenjene djeci, kao i naslovima koji su dosegnuli određeni stupanj opstojnosti.

Ključne riječi: kanon, jeftini sveščići za puk (chapbooks), moraliziranje, konstrukcija djetinjstva 